\title{
COST AND BENEFIT ANALYSIS OF ORGANIC MULCHING AND INTERCROPPING IN MAIZE CULTIVATION
}

\author{
ANANE, P.-S. ${ }^{1,2}-$ DU, Y. ${ }^{1,2}-$ WANG, T. Y. ${ }^{1,2^{*}}-$ HUANG, Z. Y. ${ }^{1,2}-$ BAI, Y. C. ${ }^{1,2}-$ AsIEDU, M. A. ${ }^{1,2}$ \\ - LIU, S. X. ${ }^{1,2^{*}}$ \\ ${ }^{I}$ College of Resources and Environmental Science, Jilin Agricultural University \\ No. 2888, Xincheng Da Jie Road, Changchun, Jilin Province 130118, China \\ (e-mail: ananepaulsimon@gmail.com,duyan0728@126.com,hhzzyy0417@163.com, \\ baiyichen96@outlook.com, Isaacpauldroid@gmail.com) \\ ${ }^{2}$ Key Laboratory of Soil Resource Sustainable Utilization for Jilin Province Commodity Grain \\ Bases, Changchun, Jilin Province, 130118, China \\ ${ }^{*}$ Corresponding author \\ e-mail: liushuxia69@163.com
}

(Received 23 $3^{\text {rd }}$ May 2019; accepted $31^{\text {st }}$ Oct 2019)

\begin{abstract}
The aim of this article was to investigate the effect of different mulching and intercropping techniques in maize cultivation with particular focus on weed control, using a randomized complete block design with four replicates to determine the financially optimum method. Field experiment was performed at two different geographical locations which were Nkakom, Nwabiagya District in the Ashanti region of Ghana and Changchun, Jilin-China during 2017 and 2018 cropping seasons, respectively. The experiment consisted of 4 treatments which were control (no mulch), maize (Zea mays L.) straw-maize, green gram (Vigna radiate)-maize intercrop and groundnut (Arachis hypogaea)-maize intercrops. Measured agronomic parameters were weed biomass, maize yield and legume yields. Green gram-maize intercrop recorded the lowest weed biomass and the control (no mulch) recorded the highest weed biomass. There were no significant differences between maize yields measured. Economic analysis of data was carried out with partial farm budgeting. The highest financial net return was obtained in the green gram-maize intercrop whiles the lowest was recorded in control (no mulch) treatment at the two different geographical locations. Keywords: legumes, organic mulch, partial budgeting, weed
\end{abstract}

\begin{abstract}
Abbreviations: WAP: weeks after planting; GG: green gram; GN: groundnut; LSD: least significant difference; NS: no significant; $\mathrm{R}_{\mathrm{MC}}$ : revenue from maize earned in the control plot; $\mathrm{R}_{\mathrm{MGG}}$ : revenue of maize earned in the green gram-maize intercrop plot; $\mathrm{R}_{\mathrm{MGN}}$ : revenue of maize earned in the groundnut-maize intercrop plot; $\mathrm{R}_{\mathrm{MMS}}$ : revenue of maize earned in the maize straw plot; $\mathrm{R}_{\mathrm{GG}}$ : revenue earned from green gram; $\mathrm{R}_{\mathrm{GN}}$ : revenue earned from groundnut; $\mathrm{Y}_{\mathrm{MC}}$ : grain yield of maize earned in the control plot; $\mathrm{Y}_{\mathrm{MGG}}$ : grain yield of maize earned in the green gram-maize intercrop plot; $\mathrm{Y}_{\mathrm{MGN}}$ : grain yield of maize earned in the groundnut-maize intercrop plot; $\mathrm{Y}_{\mathrm{Mms}}$ : grain yield of maize earned in the maize straw-maize plot; $\mathrm{Y}_{\mathrm{GG}}$ : grain yield earned from green gram; $\mathrm{Y}_{\mathrm{GN}}$ : grain yield earned from groundnut; $\mathrm{MP}_{\mathrm{M}}$ : market price of maize; $\mathrm{TC}_{\mathrm{C}}$ : total cost on the control plot; $\mathrm{TC}_{\mathrm{GG}-\mathrm{M}}$ : total cost on green gram-maize intercrop plot; $\mathrm{TC}_{\mathrm{GN}-\mathrm{M}}$ : total cost on the groundnut-maize intercrop plot; $\mathrm{TC}_{\mathrm{MS}-\mathrm{M}}$ : total cost on the maize straw-maize plot; $\mathrm{C}_{\mathrm{MS}}$ : cost of maize seeds planted; $\mathrm{C}_{\mathrm{MP}}$ : cost of planting maize seeds; $\mathrm{C}_{\mathrm{FA}}$ : cost of fertilizer and its application; $\mathrm{C}_{\mathrm{MH}}$ : cost of harvesting maize; $\mathrm{C}_{\mathrm{WC}}$ : cost of weeding the control plot; $\mathrm{C}_{\mathrm{GGS}}$ : cost of green gram seeds planted; $\mathrm{C}_{\mathrm{GGP}}$ : cost of planting green gram seeds; $\mathrm{C}_{\mathrm{WGG}}$ : cost of weeding green gram-maize intercrop plot; $\mathrm{C}_{\mathrm{GGH}}$ : cost of harvesting green gram; $\mathrm{C}_{\mathrm{GNS}}$ : cost of groundnut seeds planted; $\mathrm{C}_{\mathrm{GNP}}$ : cost of planting groundnut seeds; $\mathrm{C}_{\mathrm{WGN}}$ : cost of weeding groundnut-maize intercrop plot; $\mathrm{G}_{\mathrm{GNH}}$ : cost of harvesting groundnut; $\mathrm{C}_{\mathrm{MA}}$ : cost of maize straw application/mulching; $\mathrm{C}_{\mathrm{WM}}$ : cost of weeding maize straw-maize plot; $\mathrm{TR}_{\mathrm{C}}$ : total revenue earned in the control plot; $\mathrm{TR}_{\mathrm{GG}-\mathrm{M}}$ : total revenue earned in the green gram-maize intercrop plot; $\mathrm{TR}_{\mathrm{GN}-\mathrm{M}}$ :

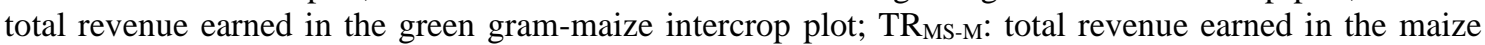
straw maize plot; $\mathrm{P}_{\mathrm{C}}$ : profit earned in the control plot; $\mathrm{P}_{\mathrm{GG}-\mathrm{M}}$ : profit earned in the green gram-maize intercrop plot; $\mathrm{P}_{\mathrm{GN}-\mathrm{M}}$ : profit earned in the groundnut-maize intercrop plot; $\mathrm{P}_{\mathrm{MS}-\mathrm{M}}$ : profit earned in the maize-straw maize plot; Eq: equation
\end{abstract}




\section{Introduction}

Maize is one of the most important crops worldwide. It is grown throughout the world, with the United States, China, and Brazil being the top three maize-producing countries in the world producing approximately 563 of the 717 million metric tons/year (Ranum et al., 2014). Maize accounts for over $50 \%$ of the total cereal production in Ghana and annual yield have been reported to be growing around 1.1\% (IFPR, 2014). Maize contains about $72 \%$ starch, $10 \%$ protein, and $4 \%$ fat, supplying an energy density of $365 \mathrm{Kcal} / 100$ gas (Nuss and Tanumihardjo, 2010) compared to rice and wheat, but has lower protein content. In Ghana maize account for $62 \%$ of total grain output. It is the largest staple crop in Ghana and the mainstay of the diet of the majority Ghanaians. Maize is also an increasingly important component of poultry feed, and to a lesser extent, the livestock feed and brewing industry. The agro-ecological zones for maize in Ghana is grouped into four, namely the Coastal savannah zone, Forest zone, Transitional zone, and Guinea savannah zone. Maize production happens in almost every part of Ghana however output differs among these agro-ecological zones (Morris et al., 1999). The Ashanti region is among the five major principal areas in maize cultivated.

China's average per capita meat consumption has quadrupled Nuss and Tanumihardjo (2010) and Schneider and Sharma (2014). In terms of the numbers of animals, China has seen a five-fold increase in pig stocks and an almost 9-fold increase in chicken since 1961 (FAO, 2013). As maize is the country's primary feed crop (Shihuang and Kaijian, 2014) the rapid expansion of maize and meat production and consumption are intrinsically linked. The principal maize production areas in China are situated in a belt of very diverse environments traversing China from northeast to southwest. Production environments can be classified into six agro-ecological regions: Northeast China, North China, YellowHuai River Valley, Northwest China, Southwest China, and South China. The provinces and prefectures included in each agro-ecological region are; Heilongjiang, Jilin, Liaoning, Inner Mongolia, Hebei, Shanxi, Shandong, Henan, Shanxi, Shaanxi, Sichuan, Guizhou, Yunnan, and Guangxi (Meng, 2008).

Because of this, serious attention should be on the sustainable production of maize and supply to curb higher prices, malnutrition, poverty, and hunger for its direct and indirect consumers. One major factor contributing to the decline in maize production arises from weed competition and its associated management constraints. Of all crop pest, weed is the commonest blooming each year on almost every farm in most areas of the world competing with crops for growth requirements (Obuo et al., 1997). Major problems caused by weeds include interfering and competing with cultivated and desirable plants for space, light, water and soil nutrients, interference with cultural operations and harvest, serving as alternate hosts for other crops pests and diseases and reducing crop output. Therefore, to attain optimal yield, weeds need to be controlled before planting a crop and be monitored during the growing season until harvesting. Inefficient weed management methods are a crucial factor in the overall decline in the yield of maize (Gianessi, 2013).

To obtain optimum growth and yield of maize, weed management becomes a pivotal factor to consider. Numerous research has identified essential techniques that could suppress weed competition but there is little attention to the economic, biological, environmental and health effects of these techniques (Omovbude and Udensi, 2012). Attention is mostly shifted towards cultural (hand-or-hoe -weeding), mechanical (slashing), chemical (pre-plant, pre or post-emergence herbicide (Omovbude and Udensi, 2012). Although all the above practices could yield positive weed management results, 
yet, associated with significant environmental, biological, health and economic setbacks when applied intensively.

The approach used in this research such as the selection of treatments and the mathematical expressions executed in calculating the total cost, total revenue and profit/net revenue has not been used elsewhere therefore making this research peculiar.

This research was based on three objectives: (1) effects of organic mulch on weed growth, (2) whether organic mulch and intercropping could reduce the cost of weed management and boost net revenue, and (3) whether the legumes used for the intercrop used could affect maize yield.

\section{Literature Review}

Intercropping is defined as the farming practice of growing two or more crops in the same space at the same time. Intercropping method ensure productivity per unit area of land. Intercropping system ensures maximum utilization of soil and environmental resources. Intercropping system is associated with socio-economic, biological and ecological returns. Besides maintaining the soil health (Prasad et al., 2008) further reported an efficient utilization of growth resources with intercropping when with maizeblack gram intercrop.

This practice is an attractive strategy to smallholder farmers for increasing productivity and labor utilization per unit of area of available land through intensification of land use (Seran and Brintha, 2010). Intercropping cereals with legumes have a huge capacity to replenish soil mineral nitrogen through its ability to biologically fix atmospheric nitrogen (Giller, 2001). Intercropping works better by ensuring maximum yield when crops have different growth requirements such as moisture, light, nutrients and space for growth and yield. The features of an intercropping system differ with soil, climatic conditions, economic situations and preferences of the local community (Steiner, 1982).

Maize-legume intercropping system reduces the risk of total crop failure; thus when one crop fails due to pest and disease attack, there is still hope of yield gain. Maizelegume intercrop system also proves to have financial advantage over maize monocropping. Commonly, maize is intercropped with some legume crops such as cowpea, soybean, pigeon pea, groundnut and green gram.

Organic mulching, either life or dead mulch, besides its weed control ability, could make available several benefits including; increasing microbial activity in the soil, limiting soil erosion, permitting symbiotic nitrogen fixation, nutrient conservation and enhancement of biodiversity (Hartwig, 2002; Gerhards, 2018). Live mulch through intercropping compete with weeds and very effectively prevent or suppress them from growing. Dependence on the organic mulch as a weed control agent plays a significant role in integrated weed management techniques because living mulches could deal with weed control over an extended period, from the early growth stages until harvesting. Mulch and legume crops provide food and habitat for beneficial insects. They could also retain moisture, regulate soil temperature, ensure weed suppression, improve soil structure and add soil nutrients such as nitrogen (Kahangi et al., 2014). The most important attributes required for species used as living mulches are quick emergence and soil covering, short height, low water and nutrients demands (Kolota and Adamezewska, 2013).

Deepening farmer's knowledge on mulching and intercropping as weed control agent could reduce the cost of production through reducing weed competition. It could also deal 
with matters of malnutrition and prevent some conventional practices such as burning of residues after harvesting which leads to land degradation and pollution.

\section{Materials and Methods}

\section{Experimental Sites}

Field experiment was performed in two different geographical regions. The experiment was carried out in the year 2017 and 2018 at Young Adults Training Center, Nkwakom, Nwabiagya District in the Ashanti region of Ghana and Jilin Agricultural University, Changchun, Jilin-China respectively. Figures 1 and 2 represents the maps of the study areas.

\section{Sites Description of Atwima Nwabiagya-Kumasi, Ghana}

\section{Location}

In 2017, the experiment was performed at the Young Adults Training Center, Nkakom Nwabiagya District in the Ashanti region of Ghana. The area lies approximately between latitude $6^{\circ} 32^{\prime} \mathrm{N}$ and $6^{\circ} 75^{\prime} \mathrm{N}$, and between longitude $1036^{\circ}$ and $2^{\circ} 00^{\prime}$ West. It is situated in the Western part of the Ashanti Region and shares boundaries with Nkawie (to the West), Afari (to the East), Foase (to the North) and Nkoran (to the south).

\section{Topography and Drainage}

The area has an undulating topography. The lands have average heights of about $77 \mathrm{~m}$ above sea level. The high land has gentle to steep slopes. There are several wider valleys with no evidence of stream-flow. These valleys provide opportunities for rice, sugarcane and vegetable cultivation.

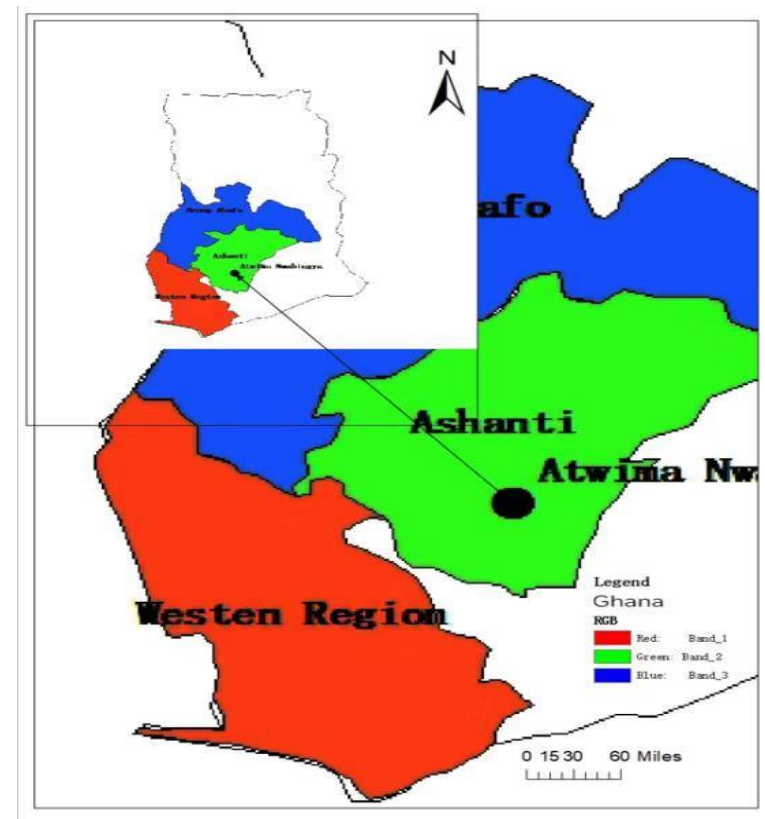

Figure 1. Map of the study area at 2017. The Atwima Nwabiagya District is in the Ashanti Region of Ghana 


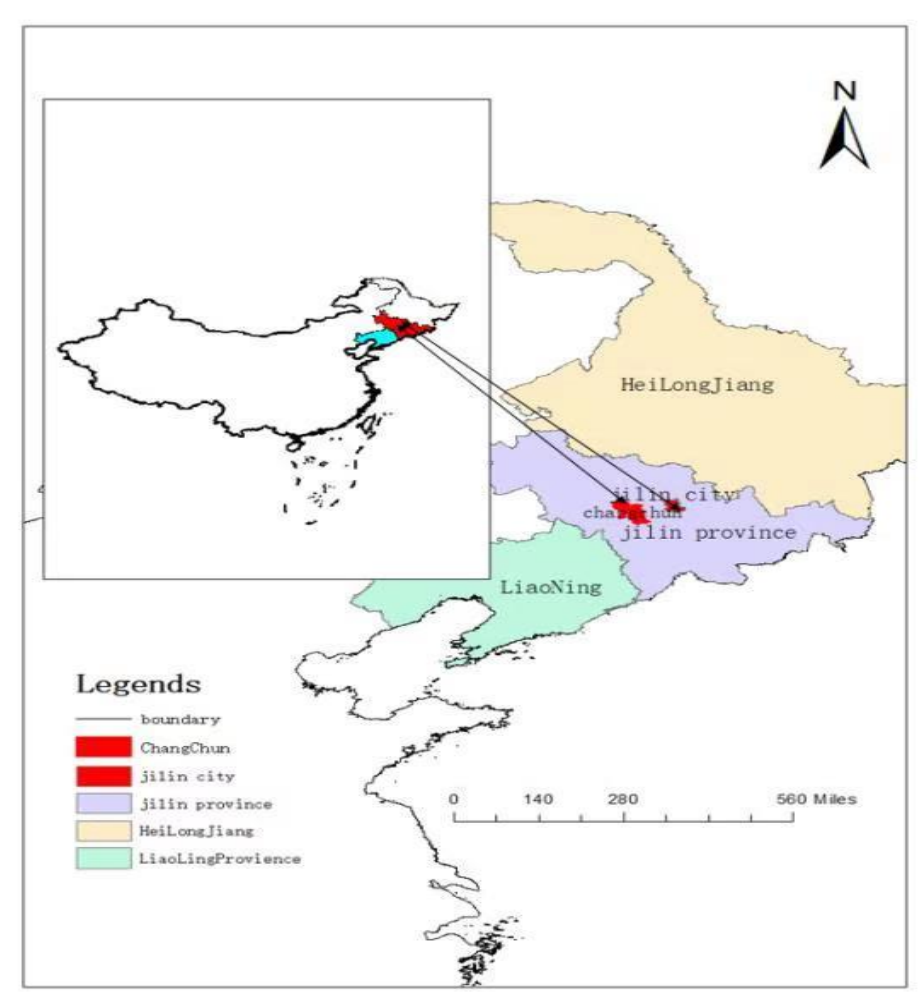

Figure 2. Map of the study area at 2018. Changchun is in Jilin Province of China

\section{Climate}

The area lies within the wet semi-equatorial zone, which is marked by double maximum with annual rainfall ranging between $170 \mathrm{~cm}$ and $185 \mathrm{~cm}$. Major rainfall season is from Mid-March to July, and the minor season is between September and mid-November. Temperature is reasonably uniform, ranging between $27^{\circ} \mathrm{C}$ (August) and $31^{\circ} \mathrm{C}$ (March). Mean relative humidity of about 87 to 91 per cent is characteristic of the area. The lowest relative humidity usually occurs in February/April when they are between 83-87 in the morning and 48-67 in the afternoon.

\section{Vegetation}

The vegetation found in the area is predominantly the semi-deciduous type. The vegetation type has primarily been disturbed by human activities (logging, farming, bush fires, etc.), thus, depriving it of its original valuable tree species, soil fauna and other forest products.

\section{Soil and Characteristics}

The soil has a high water holding capacity. The soil is marginal for mechanical cultivation. Hand cultivation is recommended. The soil is good for agriculture. They are suitable for tree and arable crops such as cocoa, citrus, oil palm, mangoes, guava, avocado, maize, cassava, yams. Their moisture-holding capacity is reasonably high, although surface layers are susceptible to dry season drought. The soils are moderately suitable for agriculture. 


\section{Pest and Diseases}

Pest and disease condition in the district is not all that serious, apart from the usual caterpillars, grasshoppers, aphids and mites, which affect some crops. Armyworm attack on maize occurs seldom in the area with the highest incidence recorded in 2017. Common diseases are fruit drop in citrus and black pods on cocoa. The common pests in animals include ticks, worms and lies.

\section{Site Description of Changchun, Jilin-China}

\section{Location}

The test site is located in the long-term positioning test field of Jilin Agricultural University, Changchun City Jilin Province northeastern China $\left(43^{\circ} 47^{\prime} \mathrm{N}, 123^{\circ} 20^{\prime} \mathrm{E}\right)$.

\section{Topography and Drainage}

The terrain is flat and open, which is a transitional zone between the eastern mountain area and the western Songliao Plain. The river runoff in Changchun City is mainly caused by atmospheric rainfall with annual total of about 11.4 billion cubic meters, surface water resources of about 1.287 billion cubic meter and groundwater resources of about 1.238 billion cubic meter.

\section{Climate}

Changchun is located in the center of the Song Liao Plain and has a semi-wet monsoon type climate. The temperature varies throughout the year. The season is defined with spring being dry and windy; summer being short and cool; autumn being sunny and warm during the day but cold at night; winter is cold, with a permanent covering of snow. The average annual temperature of Changchun is about $4.8^{\circ} \mathrm{C}$. January is the coldest month, with an average temperature of $-17.2^{\circ} \mathrm{C}$. The lowest temperature is $-39.8^{\circ} \mathrm{C}$. July is the hottest with an average temperature of about $23^{\circ} \mathrm{C}$. With the highest recorded temperature being $39.5^{\circ} \mathrm{C}$.

\section{Vegetation}

The natural vegetation is prairie grass in the western plains and mixed conifer and broad-leaved deciduous forest in the eastern mountainous area. The vegetation in the east of mountains includes tree species such as Japanese red pine, Manchurian ash, fish-scale pine, larch, birch, oak, willow, elm and the Manchurian walnut.

\section{Soil and Characteristics}

There are two main types of soils in the province: podosols in the eastern mountainous region and black earth in the western plains. The podosols occur in several forms and are of both high and low fertility. Central and west Jilin are the areas of the black earths of the northeastern plains. It is of high productivity and contains a high percentage of organic matter, and they form good arable land.

\section{Pest and Diseases}

Diseases are mainly silk smut and pest are mostly aphids, army worm and white star. 


\section{Soil Parameters Tested}

Land on which the experiment was performed in Ghana was initially tilled conventionally through residue burning and plowing with the use of a hoe. From early 2016, the area was gradually transitioning from conventional tillage to conservation tillage through soil cover, minimum disturbance and crop rotation. In China the land was under continuous tillage with the use of bigger machinery for fertilizer broadcasting.

The parameters of soil we tested were $\mathrm{pH}$, temperature, moisture, soil organic matter, total nitrogen, alkali hydrolyzed nitrogen, available phosphorus, total phosphorus, available potassium and total phosphorus. We measured soil $\mathrm{pH}$ on 1:10 (w/v) ratio in distilled water using $\mathrm{pH}$ meter, we tested soil moisture and temperature with a hand-held moisture meter and thermography, respectively. We determined soil organic matter by dichromate oxidation with external heat and titration with ferrous ammonium sulphate. We measured soil alkali nitrogen using the Illinois soil nitrogen test diffusion. We determined soil total potassium calorimetrically using the molybdate method. We determined soil available phosphorus (AP) calorimetrically based on the Olsen method. We extracted soil total potassium by incubation with sodium hydroxide, and we extracted soil available potassium by incubating with $1.0 \mathrm{~mol} \mathrm{~L}^{-1}$ ammonium acetate for $0.5 \mathrm{~h}$, followed by filtration. Tables 1 and 2 below summarizes the soil parameters tested at each experimental site before the commencement of the study. Soil parameters tested in 2018 (China) were more as compared to that in 2017 (Ghana) due to the availability of laboratory equipment that was in China.

\section{Treatments and Experimental Design}

Treatment involved in the research consisted of organic mulching and different intercropping methods. The treatments were green gram-maize intercrop, groundnutmaize intercrop, maize straw-maize and control (no mulch). We arranged the treatments in a randomized complete block design (RCBD) with four replications. Each one plot occupied a total land area of $3.9 \mathrm{~m} \mathrm{x} 8 \mathrm{~m}\left(31.2 \mathrm{~m}^{2}\right)$ with an alleyway of $1 \mathrm{~m}$ way among plots and $1 \mathrm{~m}$ among replicates given a total land area of $19.6 \mathrm{~m}$ x $36 \mathrm{~m}$ $\left(705 \mathrm{~m}^{2}\right)$ approximately $(0.07 \mathrm{ha})$. All plots were kept clean of weeds before we planted. We applied all mulching procedures the same day as maize seeds were planted. We sowed maize seeds with between and within row spacing of $65 \mathrm{~cm}$ and $25 \mathrm{~cm}$, respectively. Maize varieties we used for the experiment in Ghana and in China were obatampa and Ji nong yu 885, respectively. With green gram-maize and groundnutmaize intercrops, we established two rows of the legumes spaced $21 \mathrm{~cm}$ between rows and $25 \mathrm{~cm}$ within rows between two rows of maize $(2: 2)$. We kept the maize straw obtained between and within the maize rows which completely covered the entire maize straw-maize plot. In 2017, the maize straw we used for the experiment in Ghana was obtained from 2016 minor season maize residues which we gathered to mulch the plot. Also in 2018, maize straw we used for the experiment in China was obtained from residues left on the field after 2017 harvest. We kept the control plot bare before planting maize. 
Table 1. Chemical properties of the experimental site before the commencement of the study 2017 season at the Young Adults Training Center Nkaakom-Ashanti, Ghana

\begin{tabular}{c|c}
\hline Soil Properties & Values \\
\hline $\mathrm{Ph}(1: 10 \mathrm{w} / \mathrm{v})$ & 5.54 \\
Moisture $(\%)$ & 18.5 \\
Temperature $\left({ }^{\circ} \mathrm{C}\right)$ & 22.3 \\
\hline
\end{tabular}

Table 2. Chemical properties of the experimental site before the commencement of the study 2018 season at Jilin Agricultural University, Changchun City Jilin Province China

\begin{tabular}{c|c}
\hline Soil Properties & Values \\
\hline Ph $(1: 10 \mathrm{w} / \mathrm{v})$ & 6.1 \\
Moisture $(\%)$ & 20.6 \\
Temperature $\left({ }^{\circ} \mathrm{C}\right)$ & 21.1 \\
Organic matter $(\mathrm{g} / \mathrm{kg})$ & 22.8 \\
Total Nitrogen $(\mathrm{g} / \mathrm{kg})$ & 1.399 \\
Total Phosphorus $(\mathrm{g} / \mathrm{mg})$ & 0.53 \\
Total Potassium $(\mathrm{g} / \mathrm{kg})$ & 23.19 \\
Alkali Hydrolyzed Nitrogen $(\mathrm{mg} / \mathrm{kg})$ & 125 \\
Available Phosphorus $(\mathrm{mg} / \mathrm{kg})$ & 35.1 \\
Available Potassium $(\mathrm{mg} / \mathrm{kg})$ & 156 \\
\hline
\end{tabular}

We performed the experiments at both locations under rain-fed condition but due to shortage of rainfall during the first and second week in 2018 (China), we watered the experimental plots through sprinkler irrigation. We performed thinning 20 days after planting to obtain one plant per stand for maize and two plants per stand for both legumes. Total plant populations were 62,500 plants/h, 400,000 plants/h and 400,000 plant/h for maize green gram and groundnut respectively. Table 3 further explains the sowing rate of seeds in each treatment. Sowing rates were similar in both geographical regions. We applied NPK fertilizer in a ratio of 27:12:11 to the maize in a localized manner after thinning. Figures 3, 4, 5, 6 represent the various experimental treatments. Images were taken at 12 weeks after planting during 2018 season at Jilin Agricultural University, China. We could not repeat the experiment at both locations due to high incident of armyworm attack on maize in the minor season in Ghana and limited time for the experiment in China.

Table 3. Sowing rate of maize, green gram, and groundnut 2017 (Ghana) and 2018 (China) seasons

\begin{tabular}{c|c|c|c}
\hline TREATMENT & MAIZE & GREEN GRAM & GROUNDNUT \\
\hline CONTROL & $62,500(52 \mathrm{Kg} / \mathrm{ha})$ & - & - \\
GG-MAIZE & $62,500(52 \mathrm{Kg} / \mathrm{ha})$ & $400,000(56 \mathrm{Kg} / \mathrm{ha})$ & - \\
INTERCROP & & - & $400,000(225 \mathrm{Kg} / \mathrm{ha})$ \\
GN-MAIZE & $62,500(52 \mathrm{Kg} / \mathrm{ha})$ & - & - \\
INTERCROP & $62,500(52 \mathrm{Kg} / \mathrm{ha})$ & & \\
MS-MAIZE &
\end{tabular}




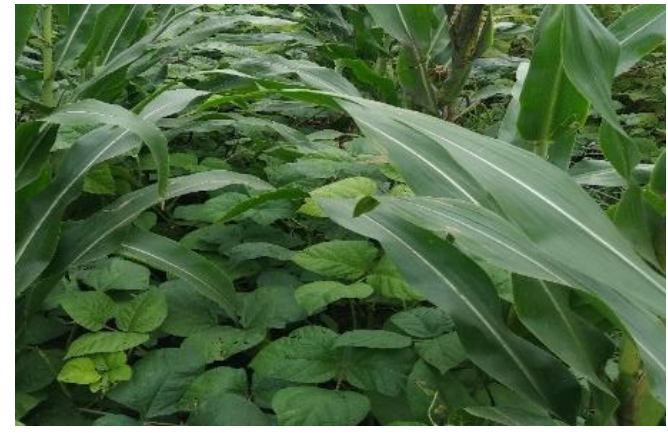

Figure 3. Green gram-maize intercrop

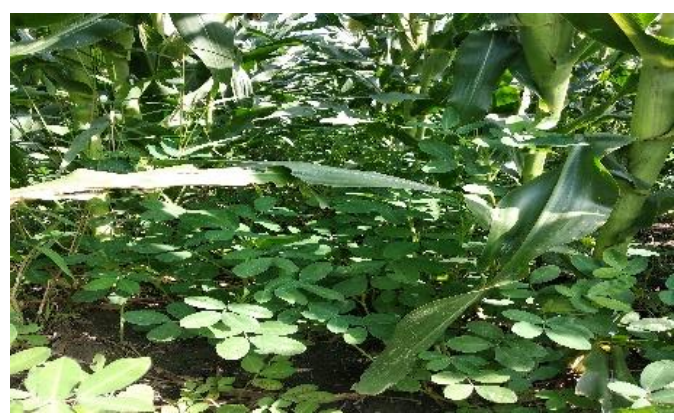

Figure 5. Control plot (no mulch)

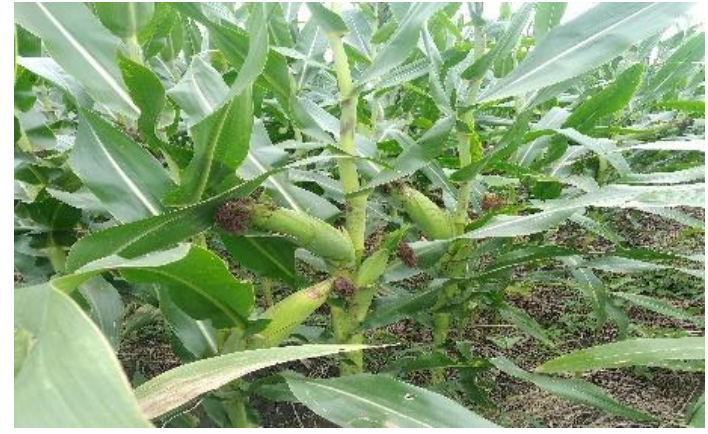

Figure 4. Maizestraw-maize

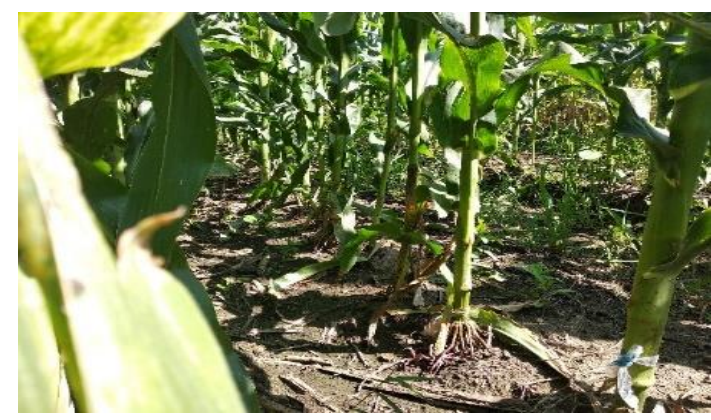

Figure 6. Groundnut-maize intercrop

Figures of the various treatments are presented above (images were taken at 12 weeks after planting during 2018 season at Jilin Agricultural University, China)

\section{Data Collection and Analysis}

We recorded data on weed biomass and maize yield. We also recorded grain yield of green gram and groundnut. We recorded weed biomass at 6 weeks and 12 weeks after planting from randomly selected three central rows from each experimental unit and we averaged to get weed $\mathrm{kg} / \mathrm{m}^{2}$. In determining maize kernel weight, were we harvested two rows in the middle of each plot to achieve results. We detached maize ears, threshed the seeds and weighed. We converted values to $\mathrm{kg} / \mathrm{ha}$. Other maize yield parameter we analyzed were ear length, cob diameter, number of rows per cob, number of kernels per cob and maize grain. We selected 10 ears randomly from each plots making a total of 40 ears per treatment for the analysis. We harvested two central rows of both groundnut and green gram for the analysis of $\mathrm{kg} / \mathrm{ha}$ of grain. Results of maize, green gram and groundnut grain yields at the two different geographical locations are presented in Tables 4 and 5 below.

Table 4. Maize, green gram and groundnut grain yields during 2017 season (Ghana)

\begin{tabular}{c|c|c|c}
\hline TREATMENT & $\begin{array}{c}\text { MAIZE } \\
(\mathbf{K g} / \mathbf{h a})\end{array}$ & $\begin{array}{c}\text { GREEN GRAM } \\
(\mathbf{K g} / \mathbf{h a})\end{array}$ & $\begin{array}{c}\text { GROUNDNUT } \\
\text { (Kg/ha) }\end{array}$ \\
\hline CONTROL & $10,759.4$ & - & - \\
GG-MAIZE & $10,724.5$ & $1,848.3$ & - \\
INTERCROP & $10,749.5$ & & $2,444.5$ \\
GN-MAIZE & $10,741.5$ & - & - \\
INTERCROP & & & \\
MS-MAIZE &
\end{tabular}


Table 5. Maize, green gram and groundnut grain yield during 2018 season (China)

\begin{tabular}{c|c|c|c}
\hline TREATMENT & $\begin{array}{c}\text { MAIZE } \\
\mathbf{( K g / h a )}\end{array}$ & $\begin{array}{c}\text { GREEN GRAM } \\
\mathbf{( K g / h a )}\end{array}$ & $\begin{array}{c}\text { GROUNDNUT } \\
\text { (Kg/ha) }\end{array}$ \\
\hline CONTROL & $11,219.2$ & & - \\
GG-MAIZE & 11,199 & $1,949.58$ & - \\
INTERCROP & $11,201.6$ & & $2,305.2$ \\
GN-MAIZE & $11,207.5$ & - & - \\
INTERCROP & & & - \\
MS-MAIZE &
\end{tabular}

\section{Data Analysis}

We subjected the data collected to Fisher's analysis of variance technique and LSD test at $0.05 \mathrm{P}$ was used to compare the differences among treatment means.

\section{Economic Assessment}

An economic evaluation of the different weed control methods was carried out using partial farm budget. The formula we used for calculating the various total cost, the various total revenue and the profit of the treatments are presented in the mathematical expression below. We considered these variables for the calculations:

Total cost in the control treatment involved (cost of maize seeds planted, cost of planting, cost of fertilizer application, cost of weeding the control plot and cost of harvesting maize all added together), total cost involved in maize straw-maize treatment involved (total cost of maize cultivation, cost of mulch application and cost of weeding all added together) and total cost involved in legume-maize intercrops involved (total cost of maize cultivation, cost of legume seeds planted, cost of planting legumes seeds, cost of weeding, and cost of harvesting legumes all added together). Total income earned from the control treatment involved only the revenue earned from maize, total revenue earned from maize straw-maize treatment also involved only the revenue earned from maize, total revenue earned from maize-legume intercrops involved (revenue earned from maize and the revenue earned from legume added together).

The profits earned from each treatment were calculated by subtracting the costs involved in each treatment from the revenues obtained from each treatment.

\section{Results}

Results obtained at the two different geographical regions at the different growing seasons are presented below. Results of weed biomass at the different locations are presented in Table 6. The results of maize yield parameters are presented in Tables 7, 8, $9,10,11$, and 12. Results of cost and benefit analysis obtained from the treatments are presented in Tables 13 and 14. 
Table 6. Effects of different organic mulching procedures on the weed biomass $(\mathrm{kg} / \mathrm{m} 2)$ during 2017 and 2018 seasons

\begin{tabular}{c|c|c|c|c}
\hline & \multicolumn{2}{|c|}{2017} & \multicolumn{2}{c}{$\mathbf{2 0 1 8}$} \\
\hline Treatments & 6 WAP & 12 WAP & 6 WAP & 12 WAP \\
\hline Control (no mulch) & $12.83 \mathrm{a}$ & $11.56 \mathrm{a}$ & $10.26 \mathrm{a}$ & $8.67 \mathrm{a}$ \\
GG-maize intercrop & $4.76 \mathrm{c}$ & $3.48 \mathrm{~d}$ & $4.53 \mathrm{c}$ & $2.61 \mathrm{~d}$ \\
GN-maize intercrop & $8.73 \mathrm{~b}$ & $6.16 \mathrm{c}$ & $7.24 \mathrm{~b}$ & $4.62 \mathrm{c}$ \\
Maize straw-maize & $2.57 \mathrm{~d}$ & $8.16 \mathrm{~b}$ & $2.08 \mathrm{~d}$ & $6.45 \mathrm{~b}$ \\
LSD (5\%) & 1.99 & 1.64 & 1.59 & 1.23 \\
\hline
\end{tabular}

Table 7. Effects of different mulching methods on maize cob diameter $(\mathrm{cm})$, ear length $(\mathrm{cm})$ and ear weight during 2017 season

\begin{tabular}{c|c|c|c}
\hline Treatments & cob diameter $(\mathbf{c m})$ & ear length $(\mathbf{c m})$ & ear weight $(\mathbf{k g} / \mathbf{m} 2)$ \\
\hline Control (no mulch) & $3.01 \mathrm{a}$ & $21.19 \mathrm{~b}$ & $3.51 \mathrm{c}$ \\
GG-maize intercrop & $3.05 \mathrm{a}$ & $21.31 \mathrm{~b}$ & $3.44 \mathrm{c}$ \\
GN-maize intercrop & $2.98 \mathrm{a}$ & $21.36 \mathrm{~b}$ & $3.43 \mathrm{c}$ \\
Maize straw-maize & $3.06 \mathrm{a}$ & $21.54 \mathrm{~b}$ & $3.61 \mathrm{c}$ \\
LSD (5\%) & $\mathrm{NS}$ & $\mathrm{NS}$ & $\mathrm{NS}$ \\
\hline
\end{tabular}

Table 8. Effects of different organic mulching methods on the number of kernel rows/cob, number of kernels/row and number of kernel /cob of maize during the 2017 season

\begin{tabular}{c|c|c|c}
\hline Treatments & rows/cob & kernels/row & kernels/cob \\
\hline Control (no mulch) & $18 \mathrm{a}$ & $38 \mathrm{~b}$ & $618 \mathrm{c}$ \\
GG-maize intercrop & $17 \mathrm{a}$ & $38 \mathrm{~b}$ & $616 \mathrm{c}$ \\
GN-maize intercrop & $17 \mathrm{a}$ & $38 \mathrm{~b}$ & $661 \mathrm{c}$ \\
Maize straw-maize & $18 \mathrm{a}$ & $39 \mathrm{~b}$ & $677 \mathrm{c}$ \\
LSD (5\%) & $\mathrm{NS}$ & $\mathrm{NS}$ & $\mathrm{NS}$ \\
\hline
\end{tabular}

Table 9. Effects of different organic mulching methods on 100 seed weight and maize grain during 2017 season

\begin{tabular}{c|c|c|c}
\hline Treatments & 100 seed weight $($ wet $)(\mathbf{g})$ & 100 seed weight $(\mathbf{d r y})(\mathbf{g})$ & maize grain $\mathbf{~ k g} / \mathbf{m}^{\mathbf{2}}$ \\
\hline Control (no mulch) & $44.38 \mathrm{a}$ & $32.77 \mathrm{~b}$ & $10.28 \mathrm{c}$ \\
GG-maize intercrop & $40.34 \mathrm{a}$ & $32.09 \mathrm{~b}$ & $10.24 \mathrm{c}$ \\
GN-maize intercrop & $40.79 \mathrm{a}$ & $31.41 \mathrm{~b}$ & $10.22 \mathrm{c}$ \\
Maize straw-maize & $40.98 \mathrm{a}$ & $31.64 \mathrm{~b}$ & $10.25 \mathrm{c}$ \\
LSD (5\%) & $\mathrm{NS}$ & $\mathrm{NS}$ & $\mathrm{NS}$ \\
\hline
\end{tabular}


Table 10. Effects of different mulching methods on maize cob diameter $(\mathrm{cm})$, ear length $(\mathrm{cm})$ and ear weight during 2018 season

\begin{tabular}{c|c|c|c}
\hline Treatments & cob diameter $(\mathbf{c m})$ & ear length $(\mathbf{c m})$ & ear weight $(\mathbf{k g} / \mathbf{m} \mathbf{)})$ \\
\hline Control (no mulch) & $3.07 \mathrm{a}$ & $20.98 \mathrm{~b}$ & $3.40 \mathrm{c}$ \\
GG-maize intercrop & $3.11 \mathrm{a}$ & $21.09 \mathrm{~b}$ & $3.34 \mathrm{c}$ \\
GN-maize intercrop & $3.04 \mathrm{a}$ & $21.44 \mathrm{~b}$ & $3.32 \mathrm{c}$ \\
Maize straw-maize & $3.67 \mathrm{a}$ & $21.32 \mathrm{~b}$ & $3.51 \mathrm{c}$ \\
LSD (5\%) & $\mathrm{NS}$ & $\mathrm{NS}$ & $\mathrm{NS}$ \\
\hline
\end{tabular}

Table 11. Effects of different organic mulching methods on rows/cob, kernels/row and kernel/cob of maize 2018 season

\begin{tabular}{c|c|c|c}
\hline Treatments & rows/cob & kernels/row & kernels/cob \\
\hline Control (no mulch) & $16 \mathrm{a}$ & $38 \mathrm{~b}$ & $592 \mathrm{c}$ \\
GG-maize intercrop & $16 \mathrm{a}$ & $36 \mathrm{~b}$ & $576 \mathrm{c}$ \\
GN-maize intercrop & $16 \mathrm{a}$ & $36 \mathrm{~b}$ & $576 \mathrm{c}$ \\
Maize straw-maize & $16 \mathrm{a}$ & $37 \mathrm{~b}$ & $592 \mathrm{c}$ \\
LSD (5\%) & $\mathrm{NS}$ & $\mathrm{NS}$ & $\mathrm{NS}$ \\
\hline
\end{tabular}

Table 12. Effects of different mulching methods on 100 seed weight and maize grain yield during 2018 season

\begin{tabular}{|c|c|c|c|}
\hline Treatments & 100 seed weight (wet) & 100 seed weight (dry) & maize grain $\mathrm{kg} / \mathrm{m}^{2}$ \\
\hline Control (no mulch) & $43.04 \mathrm{a}$ & $31.66 \mathrm{~b}$ & $11.18 \mathrm{c}$ \\
\hline GG-maize intercrop & $39.14 a$ & $29.16 \mathrm{~b}$ & $11.15 \mathrm{c}$ \\
\hline GN-maize intercrop & $39.75 \mathrm{a}$ & $29.72 b$ & $11.17 \mathrm{c}$ \\
\hline Maize straw-maize & $39.74 a$ & $31.16 \mathrm{~b}$ & $11.17 \mathrm{c}$ \\
\hline $\operatorname{LSD}(5 \%)$ & NS & NS & NS \\
\hline
\end{tabular}

\section{Weed Biomass}

Results obtained showed similar results at the two different geographical locations. Weed biomass obtained showed significant differences at each sampling times at the two geographical locations where the experiment was performed. In both sampling times, the control treatment which had no mulch recorded the highest weed biomass at both locations. At 6 WAP, maize straw-maize treatment recorded the least weed biomass compared to both legume-maize intercrops at the two locations. At 12 WAP maize-green gram treatment recorded the least weed biomass followed by maize-groundnut treatment.

\section{Maize Yield Parameters}

Maize yield parameters measured showed no significant differences between treatments at the two geographical locations.

\section{Economic Assessment (Cost and Benefit Analysis)}

The results obtained in 2017 presented the highest net revenue under green gram-maize inter-crop followed by groundnut-maize intercrop whiles the control (no mulch) treatments recording the least net revenue. Similarly, in 2018 green gram-maize recorded the highest net income followed by groundnut-maize whiles the control (no mulch) recorded the least net income. 
Table 13. Cost and benefit analysis during the 2017 cropping season (Nwabiagya-AshantiGhana)

\begin{tabular}{|c|c|c|c|c|c|c|c|c|c|c|c|c|c|c|c|c|c|}
\hline \multirow{2}{*}{ Treatments } & \multirow{2}{*}{$\begin{array}{c}\text { Cost of } \\
\text { legume seds } \\
\text { planted GH } \\
\text { (USD)/ ha }\end{array}$} & \multirow{2}{*}{$\begin{array}{c}\text { Time of } \\
\text { Planting } \\
\text { legumes } / \\
\text { mulching } \\
\text { (man-hr/ha) }\end{array}$} & \multirow{2}{*}{\begin{tabular}{|c|} 
Cost of \\
Planting \\
legumes/ \\
mulching \\
GHC(USD) \\
/ha
\end{tabular}} & \multicolumn{2}{|c|}{$\begin{array}{l}\text { Time of Weed Control } \\
\text { (man-hr/ha) }\end{array}$} & \multicolumn{2}{|c|}{$\begin{array}{l}\text { Cost of Weed Control } \\
\text { GHC (USD)/ ha }\end{array}$} & \multirow{2}{*}{$\begin{array}{c}\text { Time of } \\
\text { Harvesting } \\
\text { legumes } \\
\text { man-hrs/ha }\end{array}$} & \multirow{2}{*}{$\begin{array}{c}\text { Cost of } \\
\text { harvesting } \\
\text { legumes } \\
\text { GHC } \\
\text { (USD)/ha }\end{array}$} & \multirow{2}{*}{$\begin{array}{c}\text { Total Cost of } \\
\text { weed control } \\
\text { GHC (USD) } \\
\text { hat }\end{array}$} & \multirow{2}{*}{$\begin{array}{c}\text { Total cost of } \\
\text { maize } \\
\text { cultivation } \\
\text { GCC (USD) } \\
\text { /ha }\end{array}$} & \multirow{2}{*}{$\begin{array}{c}\text { Legume } \\
\text { yields } \\
\text { obtained } \\
\text { Kg/ha }\end{array}$} & \multirow{2}{*}{\begin{tabular}{|c|} 
Revenue \\
from legumes \\
GHC(USD)/ \\
ha
\end{tabular}} & \multirow{2}{*}{\begin{tabular}{|c} 
Maize yield \\
obtained \\
Kghha
\end{tabular}} & \multirow{2}{*}{\begin{tabular}{|c|} 
Revenue \\
from maize \\
GHC (USD)/ \\
ha
\end{tabular}} & \multirow{2}{*}{$\begin{array}{c}\text { Total } \\
\text { Revenue } \\
\text { GHC (USD)/ } \\
\text { ha }\end{array}$} & \multirow{2}{*}{\begin{tabular}{|c} 
Profit (Net \\
Revenue) \\
GHC \\
(USD)/ha
\end{tabular}} \\
\hline & & & & 6 WAP & 12 WAP & $6 \mathrm{WAP}$ & $12 \mathrm{WAP}$ & & & & & & & & & & \\
\hline $\begin{array}{l}\text { Control (zero } \\
\text { mulch) }\end{array}$ & - & - & - & 186 & 116.00 & $\left|\begin{array}{c}1,953 \\
\text { (399 USD) }\end{array}\right|$ & $\mid \begin{array}{c}1,218 \\
\text { (249 USD) }\end{array}$ & - & - & $\begin{array}{c}3,171 \text { (647 } \\
\text { USD) }\end{array}$ & $\begin{array}{c}3,136 \text { (640 } \\
\text { USD) }\end{array}$ & - & - & $10,759.4$ & $\begin{array}{c}21,518.8(4, \\
391 \text { USD) }\end{array}$ & \begin{tabular}{|l|}
$21,519(4$, \\
392 USD)
\end{tabular} & $\begin{array}{l}15,212 \text { (3, } \\
104 \text { USD) }\end{array}$ \\
\hline $\begin{array}{c}\text { Green gram- } \\
\text { maize } \\
\text { intercrop }\end{array}$ & $\begin{array}{l}847(1711 \\
\text { USD) }\end{array}$ & 79 & $\begin{array}{c}829.5(169 \\
\text { USD) }\end{array}$ & 85 & 37 & $\begin{array}{c}893 \text { (182 } \\
\text { USD) }\end{array}$ & $\begin{array}{c}389 \text { (79 } \\
\text { USD) }\end{array}$ & 89 & $\begin{array}{l}935 \text { (191 } \\
\text { USD) }\end{array}$ & $\begin{array}{c}3,893(795 \\
\text { USD) }\end{array}$ & $\begin{array}{c}3,136 \text { (640 } \\
\text { USD) }\end{array}$ & $1,848.3$ & $\begin{array}{c}18,483(3, \\
772 \text { USD) }\end{array}$ & $10,724.5$ & $\begin{array}{l}21,449 \text { (4, } \\
377 \text { USD) }\end{array}$ & $\begin{array}{l}39,932(8, \\
149 \text { USD) }\end{array}$ & $\begin{array}{l}32,903 \text { (6, } \\
715 \text { USD) }\end{array}$ \\
\hline $\begin{array}{c}\text { Groundnut- } \\
\text { maize } \\
\text { interrerp }\end{array}$ & $\begin{array}{c}900(181 \\
\text { USD) }\end{array}$ & 79 & $\begin{array}{c}829.5(169 \\
\text { USD) }\end{array}$ & 93 & 51 & $\begin{array}{c}977 \text { (199 } \\
\text { USD) }\end{array}$ & $\begin{array}{c}536(109 \\
\text { USD) }\end{array}$ & 89 & $\begin{array}{l}935 \text { (191 } \\
\text { USD) }\end{array}$ & $\begin{array}{c}4,177(853 \\
\text { USD) }\end{array}$ & $\begin{array}{c}3,136(640) \\
\text { USD) }\end{array}$ & $2,444.5$ & $\begin{array}{l}7333.5 \text { (1, } \\
496 \text { USD) }\end{array}$ & $10,749.5$ & $\begin{array}{l}21,499(4, \\
388 \text { USD) }\end{array}$ & $\begin{array}{l}28,833(5, \\
884 \text { USD) }\end{array}$ & $\begin{array}{l}21,520(4, \\
392 \text { USD) }\end{array}$ \\
\hline $\begin{array}{l}\text { Maize straw- } \\
\text { maize }\end{array}$ & - & 56 & $\begin{array}{l}588(120 \\
\text { USD) }\end{array}$ & 61 & 98 & $\begin{array}{c}641 \text { (131 } \\
\text { USD) }\end{array}$ & $\begin{array}{c}1,029 \\
(210 \text { USD) }\end{array} \mid$ & - & - & $\begin{array}{c}2,258(461 \\
\text { USD) }\end{array}$ & $\begin{array}{c}3,136(640 \\
\text { USD) }\end{array}$ & - & - & $10,741.5$ & $\begin{array}{l}21,483 \text { (4, } \\
384 \text { USD) }\end{array}$ & $\begin{array}{l}21,483(4, \\
384 \text { USD) }\end{array}$ & $\begin{array}{c}16,089 \\
(3283 \\
\text { USD) }\end{array}$ \\
\hline \multicolumn{7}{|c|}{$* * K g$ of Groundnut planted per ha $=225 \mathrm{Kg}$} & $* * \mathrm{Kg}$ of $\mathrm{m}$ & naize plan & ed per ha & $=52 \mathrm{Kg}$ & & & \multicolumn{5}{|c|}{ **Time of fertilizer application $=30 \mathrm{hrs}$} \\
\hline ***ast o & o $1 \mathrm{Kg}$ of $\mathrm{C}$ & Groundnut & seeds plan & $\mathrm{ed}=4$ & $\mathrm{HC}(0.8 \mathrm{l}$ & USD) & **Cost of & $1 \mathrm{Kg}$ of $\mathrm{M}$ & aize seeds & planted $=$ & $=5 \mathrm{GHC}(1$ & USD) & **Time & of harvest & ing $=45 \mathrm{~h}$ & & \\
\hline \multicolumn{7}{|c|}{ **Price of $1 \mathrm{Kg}$ of Groundnut sold $=3 \mathrm{GHC}$ (0.6 USD) } & \multicolumn{11}{|c|}{$* *$ Price of $1 \mathrm{Kg}$ of Maize seeds sold $=2 \mathrm{GHC}(0.4 \mathrm{USD})$} \\
\hline \multicolumn{7}{|c|}{$* * \mathrm{Kg}$ of Green gram planted per ha $=56.5 \mathrm{Kg}$} & \multicolumn{11}{|c|}{$* * \mathrm{Kg}$ of fertilizer applied per ha $=419.87 \mathrm{Kg}$} \\
\hline \multicolumn{7}{|c|}{$* *$ Cost of $1 \mathrm{Kg}$ of Green gram seeds planted $=15 \mathrm{GHC}$ (3.1 USD) } & \multicolumn{11}{|c|}{${ }^{* *}$ Cost of $1 \mathrm{Kg}$ of fertilizer=4 GHC ( $\left.0.8 \mathrm{USD}\right)$} \\
\hline \multicolumn{7}{|c|}{$* *$ Price of $1 \mathrm{Kg}$ of Green gram seeds sold= $10 \mathrm{GHC}(2 \mathrm{USD})$} & \multicolumn{11}{|c|}{$* *$ Time of planting maize $(\mathrm{man}-\mathrm{hr} / \mathrm{ha})=39 \mathrm{hrs}$} \\
\hline
\end{tabular}

Table14. Cost and benefit analysis during the 2018 cropping season (Changchun, Jilin-China)

\begin{tabular}{|c|c|c|c|c|c|c|c|c|c|c|c|c|c|c|c|c|c|}
\hline \multirow{2}{*}{ Treatments } & \multirow{2}{*}{$\begin{array}{c}\text { Cost of } \\
\text { legume seeds } \\
\text { planted } \\
\text { RMB } \\
\text { (USD)/ha }\end{array}$} & \multirow{2}{*}{$\begin{array}{c}\text { Time of } \\
\text { Planting } \\
\text { legumes } / \\
\text { mulching } \\
\text { (man-hr/ hal }\end{array}$} & \multirow{2}{*}{$\begin{array}{c}\text { Cost of } \\
\text { Planting } \\
\text { legumes } / \\
\text { mulching } \\
\text { RMB (USD)// } \\
\text { ha }\end{array}$} & \multicolumn{2}{|c|}{$\begin{array}{l}\text { Time of Weed Control } \\
\text { (man-lhr/ ha) }\end{array}$} & \multicolumn{2}{|c|}{$\begin{array}{l}\text { Cost of Weed Control } \\
\text { RMB (USD)/ha }\end{array}$} & \multirow{2}{*}{\begin{tabular}{|c} 
Time of \\
Harvesting \\
legumes \\
man-hrsh/ha
\end{tabular}} & \multirow{2}{*}{$\begin{array}{c}\text { Cost of } \\
\text { harvesting } \\
\text { legumes } \\
\text { RMB } \\
\text { (USD)/ha }\end{array}$} & \multirow{2}{*}{$\begin{array}{l}\text { Total Cost of } \\
\text { weed control } \\
\text { RMB(USD)/h } \\
\text { a }\end{array}$} & \multirow{2}{*}{\begin{tabular}{|c} 
Total cost of \\
maize \\
cultivation \\
RMB \\
(USD)/ha
\end{tabular}} & \multirow{2}{*}{$\begin{array}{c}\text { Legume yieds } \\
\text { obtained } \\
\text { Kg/ha }\end{array}$} & \multirow{2}{*}{\begin{tabular}{|c} 
Revenue \\
from legumes \\
RMB \\
(USD)/ha
\end{tabular}} & \multirow{2}{*}{$\begin{array}{l}\text { Maize yield } \\
\text { Kg/ha }\end{array}$} & \multirow{2}{*}{\begin{tabular}{|c} 
Revenue \\
from maze \\
RMB \\
(USD)/ha
\end{tabular}} & \multirow{2}{*}{$\begin{array}{c}\text { Total } \\
\text { Revenue } \\
\text { RMB } \\
\text { (USD)/ha }\end{array}$} & \multirow{2}{*}{$\begin{array}{l}\text { Profit (Net } \\
\text { Revenue) } \\
\text { RMB } \\
\text { (USD)/ha }\end{array}$} \\
\hline & & & & $6 \mathrm{WAP}$ & 12 WAP & $6 \mathrm{WAP}$ & $12 \mathrm{WAP}$ & & & & & & & & & & \\
\hline $\begin{array}{c}\text { Control (zero } \\
\text { mulch) }\end{array}$ & - & - & - & 179 & 128.00 & $\begin{array}{c}2,685 \\
(389 \text { USD) }\end{array}$ & $\begin{array}{c}1,920 \\
(298 \text { USD) }\end{array}$ & - & - & $\begin{array}{c}4,605 \text { (6677 } \\
\text { USD) }\end{array}$ & $\begin{array}{c}3,649 \text { (529 } \\
\text { USD) }\end{array}$ & - & - & $11,219.2$ & $\begin{array}{c}22,438 \\
(3,251 \text { USD) }\end{array}$ & $\begin{array}{c}22,438(3, \\
251 \text { USD) }\end{array}$ & $\begin{array}{c}14,184 \text { (2, } \\
055 \text { USD }\end{array}$ \\
\hline $\begin{array}{c}\text { Green gram- } \\
\text { maize } \\
\text { intercrop }\end{array}$ & $\begin{array}{l}989 \text { (1433 } \\
\text { USD) }\end{array}$ & 79 & $\begin{array}{c}1,185(172) \\
\text { USD) }\end{array}$ & 54 & 30 & $\begin{array}{c}810 \text { (117 } \\
\text { USD) }\end{array}$ & $\begin{array}{c}450 \text { (65 } \\
\text { USD) }\end{array}$ & 89 & $\begin{array}{c}1,335 \text { (193 } \\
\text { USD) }\end{array}$ & \begin{tabular}{|c|}
$4,769(691$ \\
USD)
\end{tabular} & $\begin{array}{c}3,649 \text { (529) } \\
\text { USD) }\end{array}$ & $1,949.58$ & $\begin{array}{l}13,647 \\
(1,978 \\
\text { USD) }\end{array}$ & 11,199 & $\begin{array}{l}22,398 \text { (3, } \\
246 \text { USD) }\end{array}$ & $\begin{array}{c}36,045 \text { (5, } \\
223 \text { USD) }\end{array}$ & $\begin{array}{l}27,627(4, \\
004 \text { USD) }\end{array}$ \\
\hline $\begin{array}{c}\text { Groundult- } \\
\text { maize } \\
\text { intercropp }\end{array}$ & $\begin{array}{c}3,038(440 \\
\text { USD) }\end{array}$ & 79 & $\begin{array}{c}1,185(172 \\
\text { USD) }\end{array}$ & 71 & 52 & $\begin{array}{c}1,065 \\
\text { (154 USD) }\end{array}$ & \begin{tabular}{|c}
$780(113$ \\
USD)
\end{tabular} & 89 & $\begin{array}{c}1,335(193 \\
\text { USD) }\end{array}$ & $\begin{array}{c}7,403(1,073 \\
\text { USD) }\end{array}$ & $\begin{array}{c}3,649 \text { (529 } \\
\text { USD) }\end{array}$ & $2,305.21$ & $\begin{array}{l}9220.8 \\
(1,336 \\
\text { USD) }\end{array}$ & 11.201 .6 & $\begin{array}{l}22,403(3, \\
247 \text { USD) }\end{array}$ & $\begin{array}{c}31,624(4, \\
583 \text { USD) }\end{array}$ & $\begin{array}{l}20,572 \text { (2, } \\
981 \text { USD) }\end{array}$ \\
\hline $\begin{array}{c}\text { Maize straw- } \\
\text { maize }\end{array}$ & - & 56 & $\begin{array}{c}840(122 \\
\text { USD) }\end{array}$ & 33 & 102 & $\begin{array}{c}495 \text { (72 } \\
\text { USD) }\end{array}$ & $\begin{array}{c}1,530 \\
\text { (222 USD) }\end{array}$ & - & - & $\begin{array}{c}2,865(415 \\
\text { USD) }\end{array}$ & $\begin{array}{c}3,649 \text { (529 } \\
\text { USD) }\end{array}$ & - & - & $11,207.5$ & $\begin{array}{c}22,415 \text { ((3, } \\
249 \text { USD) }\end{array}$ & $\begin{array}{l}22,415(3, \\
249 \text { USD) }\end{array}$ & $\begin{array}{l}15,901(2, \\
304 \text { USD) }\end{array}$ \\
\hline \multicolumn{7}{|c|}{$* * \mathrm{Kg}$ of Groundnut planted per ha $=225 \mathrm{Kg}$} & $* * \mathrm{Kg}$ of & naize pla & d per 1 & $52 \mathrm{Kg}$ & & & \multicolumn{5}{|c|}{$* *$ Time of fertilizer application $=30 \mathrm{hrs}$} \\
\hline **Cost 0 & $\mathrm{f} 1 \mathrm{Kg}$ of & Groundnu & seeds plan & $e d=13$ & RMB ( & USD) & ***ast of & & & s planted $=$ & $=25 \mathrm{RMB}$ & (3.6 USD) & & e of har & sting $=45$ & & \\
\hline \multirow{2}{*}{\multicolumn{7}{|c|}{$* *$ Price of $1 \mathrm{Kg}$ of Groundnut seeds sold $=4 \mathrm{RMB}$ (0.6 USD) }} & \multicolumn{11}{|c|}{$* *$ Price of I kg of Maize seeds sold $=2$ RMB ( 0.3 USD) } \\
\hline \multicolumn{6}{|c|}{$* * \mathrm{Kg}$ of Green gram planted per ha $=56.5 \mathrm{Kg}$} & & \multicolumn{11}{|c|}{$* * \mathrm{Kg}$ of fertilizer applied per ha $=419.87 \mathrm{Kg}$} \\
\hline \multirow{2}{*}{\multicolumn{7}{|c|}{$\begin{array}{l}* \text { Cost of } 1 \mathrm{Kg} \text { of Green gram seeds planted }=17.5 \mathrm{RMB}(2.5 \mathrm{USD}) \\
* * \text { Price of } 1 \mathrm{Kg} \text { of Green gram seeds sold }=7 \mathrm{RMB}(1 \mathrm{USD})\end{array}$}} & \multicolumn{11}{|c|}{${ }^{* *}$ Cost of $1 \mathrm{Kg}$ of fertilizer $=4 \mathrm{RMB}(0.6 \mathrm{USD})$} \\
\hline & & & & & & & \multirow{2}{*}{\multicolumn{11}{|c|}{$* *$ Time of planting maize $(\mathrm{man}-\mathrm{hr} / \mathrm{ha})=39 \mathrm{hrs}$}} \\
\hline$*$ * Cost o & $\mathrm{f}$ Labor $=$ & $15 \mathrm{RMB} / \mathrm{h}$ & I (2.2 USL & & & & & & & & & & & & & & \\
\hline
\end{tabular}

\section{Discussion \\ Effects of Mulching and Intercropping on Weed Biomass}

Intercropping and mulching produced the least weed weight as compared to the control plot where no mulch was applied. The weed dry matter in intercrop was statistically significantly lower than sole maize. The results obtained at $6 \mathrm{WAP}$ was due to the initial uniform cover created by the maize straw which hindered weed growth requirement for emergence and establishment and also slow initial growth of legumes. At 12 weeks after planting, the results obtained was due to better legume establishment and decomposition of maize straw. The reason for this was that living cover crop competed with emerging 
and growing weed for the essential resource and prevented weed emergence and establishment more than dead mulch. The control plot (no mulch) recorded the highest weed biomass at each sampling times. The results obtained are in line with the findings of (Bilalis et al., 2010) who both obtained highest weed dry matter in maize mono cropping as compared to intercrop systems thus considering maize-bean and maizecowpea and other maize-legume intercrops even though different from the treatments observed in this experiment. Bilalis et al. (2010) observed that intercropping maize and legumes reduce weed density when compared with maize mono-cropping as available light needed for weed to emerge decreases with intercropping. Mehmood et al. (2018) found lower weed biomass when rice straw was used as mulch in maize cultivation under rain-fed conditions. Considerable results were observed with other mulch materials in dealing with weed biomass.

Also in their findings weed biomass increased on the plot where live mulch (soya beanmaize intercrop) was used as weed control agent during the early stages of growth as compared with the weed biomass of rice straw mulch which is in direct connection with our findings. Wayayok et al. (2014) also found weed biomass density with rice straw as compared to no mulch application, which concurs with our findings even though the crop sown was rice. The suppression of weed at the early stages of growth observed in the maize straw-maize plots and later stages observed in the legume-maize plots was due to the decrease in available light for weed to emerge. Moreover, leguminous crops have a rapid canopy development which aids them competes with weeds for growth requirements such as light, water, air and nutrients hence leading to stunted and slow weed growth.

\section{Maize Yield Parameters}

\section{Effects of Intercropping on Maize Grain Yield}

An intercrop is mostly grown for the purpose of making use of interspace which is not fully utilized by main crop in early growth period. Practicing intercrop system may reduce yield of main crop, based on the species, spatial arrangement of component crops, and environmental conditions.

Maize yield parameters measure showed no significant differences among treatments at the two locations where the experiments were performed even though maize grain yield on the control plot (no mulch) was higher as compared to the other treatments. The results are in agreement with the finding of Legwaile et al. (2012) who reported no significant differences in the number of maize cobs and 100 seed weight when sole maize and maizecowpea were compared.

The insignificant difference obtained would suggest that maize that will be planted in the subsequent season in the same field will benefit from the residual nutrients set free by the leguminous crops (Nyasasi and Kisetu, 2014). The results obtained by Patel et al. (2018) disagree with the results of this research. In their findings, maize grain yield obtained from sole maize treatment was significantly higher when compared to the maizegreen gram and maize-cowpea intercropping systems. Also, the results of the research performed by Nyasasi and Kisetu (2014) also dispute our findings. In their study, there was a significant difference in the yield of sole maize as compared to that of maizecowpea intercrop. A reduction in maize yield, when inter-cropped with legumes, could be attributed to the nature of leguminous plant considered for the intercropping. Moreover, environmental factors could also lead to yield reduction as legume crops could 
compete with maize for growth and yield conditions when such conditions are not sufficiently available.

\section{Economic Assessment}

The results obtained at both locations show that a maize farmer in Ghana and China respectively could earn an additional income of 17, 691 GHC (3, 610 USD) and 13, 443 RMB (1, 923 USD) more when he/she invests in green gram-maize instead of cultivating maize alone without mulching (control treatment). A maize farmer in Ghana and China could also earn an additional income of 16, 814 GHC (3, 431 USD) and 11, 726 RMB (1, 699 USD) when he/she invest in green gram-maize instead of cultivating maize under maize straw mulch (maize straw-maize treatment). Again a maize farmer could earn an additional income of 6, 308 GHC (1, 287 USD) and 6, 388 RMB (926 USD) in Ghana and in China respectively when he/she invest in groundnut-maize instead of cultivating maize alone without mulching (control treatment). The farmer could more also earn an additional income of 5, 431 GHC (1, 108 USD) and 4, 671 RMB (677 USD) in Ghana and China higher than cultivating maize under maize straw mulch (maize strawmaize treatment).

The results clearly show that, growing maize and intercropping with legumes such as green gram and groundnut could result in higher net returns. The higher net returns earned from legumes was due to lower cost incurred for the control of weeds and the income gain from selling the harvested seeds. Even though at both locations, green gram-maize recorded the highest net returns. These results in line with the findings of Kheroar and Patra (2013) who recorded a higher monetary advantage of legume-maize intercrop over maize mono-cropping. However, in their findings-groundnut intercrop recorded the highest net returns followed by maize-green gram intercrop with sole maize, giving the lowest profit. Patel et al. (2018) found a higher maize equivalent yield and monetary advantage with maize-green gram intercrop over sole maize and maize-cowpea intercrop due to higher price of green gram. The results also agree with the findings of Kermah et al. (2017) who also found a higher monetary advantage of intercropping over sole maize cultivation; however, their focus was on cowpea-maize intercrop. Seran and Brintha (2010) also found higher cash returns with intercropping over mono- cropping. The results also concur with the findings of Yusuf et al. (2014) who found a higher net benefit with maize-soybean intercrop than sole maize and sole soya bean.

\section{Conclusions}

We concluded from the experimental findings that, the two intercropping treatments namely, green gram-maize and groundnut-maize, proved to be profitable as compared to the other treatments at both locations. This result is due to their suitability for weed control and the extra income gained from the sales of the grains harvested. Therefore, legume-maize intercrop mulching should be part of weed management techniques for smallholder maize farmers in most parts of the world as it reduces labor input, ensures land-use efficiency and provides extra income. In addition to that, organic residues added to the soil could improve the physical, biological and chemical condition of the soil by reducing soil erosion, improving the soil structure, aggregate stability, water holding capacity, porosity of the soil, enhances microbial organism multiplication and boost soil nutrients through the decomposition of organic residues. Anyway, the adoption of a specific mulching method may depend on some factors such as socioeconomic, 
environmental and mental needs and knowledge about the practices and individual perception about the methods used to achieve those needs. Culture also could influence attitude and behavior intention towards innovation which has been shown to affect the decision to adopt.

\section{Recommendations}

Further research should be done on different leguminous crops and different organic mulch material at different regions of the world to test the efficiency of leguminous crop and mulch as a general weed control agent in maize cultivation. More also, further research should consider herbicide application as one of the treatments. Finally, further research should test the residual effects of the leguminous crops and maize straw on the soil physicochemical properties.

Acknowledgments. This work was supported by funding from the National key R\&D project sub-project (2017YFD0300405--4), Natural Science Foundation of Jilin Province, China (20170101077JC).

Conflict of interests. The authors declare that they have no conflict of interests.

Ethical approval: This article does not contain any studies with human participants or animals performed by any of the authors. The article is an original paper, is not under consideration by another journal, and has not been published previously. All authors read and approved the final manuscript.

\section{REFERENCES}

[1] Bilalis, D., Papastylianou, P., Konstantas, A., Patsiali, S., Karkanis, A., Efthimiadou, A. (2010): Weed-suppressive effects of maize-legume intercropping in organic farming. International Journal of Pest Management 56(2): 173-181.

[2] Choudhary, V., Choudhury, B. (2018): A staggered maize-legume intercrop arrangement influences yield, weed smothering and nutrient balance in the eastern Himalayan region of India. - Experimental Agriculture 54(2): 181-200.

[3] FAO. (2013): FAOSTAT Pork and Chicken Data/China mainland. - http://faostat3.fao.org.

[4] Gerhards, R. (2018): Weed suppression ability and yield impact of living mulch in cereal crops. - Agriculture 8(3): 39.

[5] Gianessi, L. P. (2013): The increasing importance of herbicides in worldwide crop production. - Pest management science 69(10): 1099-1105.

[6] Giller, K. E. (2001): Nitrogen fixation in tropical cropping systems. - Cabi.

[7] Hartwig, N. L., Ammon, H. U. (2002): Cover crops and living mulches. - Weed science 50(6): 688-699.

[8] IFPRI. (2014): International Food Policy Research Institute (Ghana strategy support program, GSSP). - Ghana Agricultural News digest September 8, New GSSP policy note prepared by Arhin B. G. bulletin.

[9] Kahangi, H. K., Rajablarijani, H. R., Nasri, M. (2014): Effect of mung bean living mulch, plastic mulch and herbicides on for age maize yield and weed control. - International Journal of Agriculture and Crop Sciences 7(14): 1452.

[10] Kermah, M., Franke, A. C., Adjei-Nsiah, S., Ahiabor, B. D. K., Abaidoo, R. C., Giller, K. E. (2017): Maize-grain legume intercropping for enhanced resource use efficiency and crop productivity in the Guinea savanna of northern Ghana. - Field crops research 213: 38-50.

[11] Kheroar, S., Patra, B. C. (2013): Advantages of maize-legume intercropping systems. Journal of Agricultural Science and Technology B 3(10B): 733. 
[12] Kołota, E., Adamczewska-Sowińska, K. (2013): Living Mulches in vegetable crops production: perspectives and limitations (A reviev). - Acta Scientiarum PolonorumHortorum Cultus 12(6): 127-142.

[13] Legwaila, G., Marokane, T., Mojeremane, W. (2012): Effects of intercropping on the performance of maize and cowpeas in Botswana. - International journal of Agriculture and Forestry 2(6): 307-310.

[14] Mehmood, T., Khan, S. U., Qayyum, A., Gurmani, A. R., Ahmed, W., Liaquat, M., Farid, A. (2018): Evaluation of Organic and Inorganic Mulching as an Integrated Weed Management Strategy in Maize Under Rainfed Conditions. - Planta Daninha 36.

[15] Meng, E. C. H., Hu, R., Shi, X., Zhang, S. (2006): Maize in China: Production systems, constraints, and research priorities. - CIMMYT.

[16] Morris, M. L., Tripp, R., Dankyi, A. (1999): Adoption and impacts of improved maize production technology. - A case study of the Ghana Grains Development Project.

[17] Nuss, E. T., Tanumihardjo, S. A. (2010): Maize: a paramount staple crop in the context of global nutrition. - Comprehensive reviews in food science and food safety 9(4): 417-436.

[18] Nyasasi, B. T., Kisetu, E. (2014): Determination of land productivity under maize-cowpea intercropping system in agro-ecological zone of Mount Uluguru in Morogoro, Tanzania. Global Science research Journal 2(2): 147-157.

[19] Obuo, J., Adipala, E., Osiru, D. (1997): Weed suppression in a cowpea/sorghum intercrop. - In Proceedings 16th East African Biennial Weed Science Conference.

[20] Omovbude, S., Udensi, E. U. (2012): Profitability of selected weed control methods in maize (Zea mays L.) in Nigeria. - Journal of Animal \& Plant Sciences 15(1): 2109-2117.

[21] Patel, A. K., Ardeshna, R., Mawalia, D. K. A. K. (2018): Growth and yield of summer maize as influenced by intercropping systems. - Journal of Pharmacognosy and Phytochemistry 7(2): 1004-1007.

[22] Prasad, A., Singh, G., Upadhyay, R. (2008): Integrated weed management in maize (Zea mays L.) and maize+ blackgram. - Indian Journal of Weed Science 40(3-4): 191-192.

[23] Ranum, P., Peña-Rosas, J. P., Garcia-Casal, M. N. (2014): Global maize production, utilization, and consumption. - Annals of the New York Academy of Sciences 1312(1): 105-112.

[24] Schneider, M., Sharma, S. (2014): China's Pork Miracle? Agribusiness and Development in China's Pork Industry. - EUR-ISS-PER.

[25] Seran, T. H., Brintha, I. (2010): Review on maize based intercropping. - Journal of agronomy 9(3): 135-145.

[26] Shihuang, Z., Kaijian, H. (2010): Maize and the formal agricultural research and development system: evolution, challenges and alternatives, in Seeds and synergies: Innovation in rural development in China. - Practical Action Publishing: 1-9.

[27] Steiner, K. G. (1982): Intercropping in tropical smallholder agriculture with special reference to West Africa. - Schriftenreihe der GTZ.

[28] Wayayok, A., Soom, M. A. M., Abdan, K., Mohammed, U. (2014): Impact of Mulch on Weed Infestation in System of Rice Intensification (SRI) Farming. - Agriculture and Agricultural Science Procedia 2: 353-360.

[29] Yusuf, I. A., Aiyelari, E. A., Lawal, F. A., Alawode, V. O., Bissallah, G. (2014): Economic analysis of maize/soyabean intercrop systems by partial budget in the Guinea savannah of Nigeria. - Continental Journal of Agricultural Economics, Wilolud Journals 8(1): 13-17. 


\section{APPENDIX}

Mathematical Expressions:

$$
\begin{gathered}
R_{M C}=Y_{M C} \times M P_{M} \\
R_{M G G}=Y_{M G G} \times M P_{M} \\
R_{M G N}=Y_{M G N} \times M P_{M} \\
R_{M M S}=Y_{M M S} \times M P_{M} \\
R_{G G}=Y_{G G} \times M P_{G G} \\
R_{G N}=Y_{G N} \times M P_{G N} \\
T C_{G G-M}=C_{G G S}+C_{G G P}+C_{W G G}+C_{G G H}+C_{M S}+C_{M P}+C_{F A}+C_{M H} \\
T C_{G N-M}=C_{G N S}+C_{G N P}+C_{W G N}+C_{G N H}+C_{M S}+C_{M P}+C_{F A}+C_{M H} \\
T C_{M S}=C_{M A}+C_{W M S}+C_{M S}+C_{M P}+C_{F A}+C_{M H} \\
T R_{C}=(E q .1) \\
P_{C}=(E q .1)-(E q .7) \\
T R_{G G-M}=(E q .2)+(E q .5) \\
T R_{G N-M}=(E q .3)+(E q .6) \\
T R_{M C}=(E q .3) \\
T
\end{gathered}
$$

